ZOOLOGIA 32 (6): 469-475, December 2015

http://dx.doi.org/10.1590/S1984-46702015000600006

\title{
Zooplankton capturing by Nile Tilapia, Oreochromis niloticus (Teleostei: Cichlidae) throughout post-larval development
}

\author{
Adriana N.A. Fattah Ibrahim ${ }^{1, *}$, Maria S.M. Castilho Noll ${ }^{1} \&$ Wagner C. Valenti \\ 'Departamento de Zoologia e Botânica, Universidade Estadual Paulista. Rua Cristóvão Colombo 2265, 15054-000 São José do \\ Rio Preto, SP, Brazil. \\ 2 Instituto de Biociências e Centro de Aquicultura, Universidade Estadual Paulista. Praça Infante Dom Henrique, \\ 11330-900 São Vicente, SP, Brazil. \\ "Corresponding author. E-mail: adriana.ibrahim@gmail.com
}

\begin{abstract}
The Nile tilapia, Oreochromis niloticus (Linnaeus, 1758), uses filter feeding and visual predation to catch prey. In filter feeding, the mucus secreted in their gill rakers traps planktonic organisms. In visual predation, the fish spot and capture food, eating it directly. At different ontogenetic stages, the Nile tilapia may impact the zooplankton community differently, since it changes how it captures its prey. The objective in this study was to verify which zooplankton groups contribute to the diet of $O$. niloticus at the post-larval stage, and if the way they capture food may determine prey size. We evaluated the diet of Nile tilapia kept in ponds for four months. We randomly removed one fish per pond every month. Stomach contents and gills of fish were extracted, fixed in formaldehyde and then analyzed with an optical microscope and stereomicroscope with a micrometric ocular in order to measure the zooplankton and the gill rakers. Fish increased consumption of rotifers, and decreased the consumption of microcrustaceans considerably up to zero in the last month. The gill raker size, nevertheless, increased as tilapia grew. Therefore, negative correlations were found between raker size and size of ingested zooplankton, showing that the size of ingested prey decreases throughout this cichlid's life. Juveniles filter feed on rotifers, and actively prey on microcrustaceans. As adults, fish stop preying visually and the mucus secreted by the gill rakers trap only small individuals. Juvenile Nile tilapia filter feed and visually prey on zooplankton. However, when adults, filter-feeding plays a more important role in the way the zooplankton community is affected. The increase in the size of the Nile tilapia's gill raker does not determine the consumption of larger zooplankton prey, and the presence of mucus in these structures plays a major role for the capture of zooplankton during the cichlid's adult stage.
\end{abstract}

KEY WORDS. Filtration; microcrustaceans; predation; rotifers.

The Nile Tilapia, Oreochromis niloticus (Linnaeus, 1758), is a plankton-feeding omnivorous species native to Africa (AtTayde et al. 2007) that has been introduced in several countries, being cultured worldwide. It is a filter feeder that also uses visual predation (Beveridge \& Baird 2000). In filter feeding, mucus is secreted in the gill rakers, allowing the fish to retain planktonic organisms (LAzZaro 1987, SANDERSON et al. 1996, Zavala-CAMIN 1996). In visual predation, fish spot and capture the food, eating it directly (LAzZARo 1987). According to ATTAYDE et al. (2006), omnivorism allows the species to survive when the concentration of predators in the environment is high, and since the Nile tilapia is an exotic species, it also has competitive advantage over local fish communities. The negative effect of Nile tilapia populations on the zooplankton can prevent strictly zooplanktivorous fish communities from establishing (AтTAYDE et al. 2007). The ingestion of cladocera by tilapia increases in proportion to the concentration this zooplankton group (ELHIgzi et al. 1995) and tilapia biomass increases proportionally to increasing organic fertilization in culture ponds (Diana et al. 1991). Plankton ingestion is more prevalent in juvenile tilapia than in adults (AtTayde \& Menezes 2008). The tilapia also influences the trophic cascade of phytoplankton communities and contributes to eutrophication by top-down and bottom-up ecological effects, selecting large algae by filtration (cyanobacteria and diatoms), which leads to a proliferation of chlorophytes (Figueredo \& Giani 2005). The predilection for large phytoplankton was also demonstrated by TURKER et al. (2003a, b) who observed a decrease in green algae and cyanobacteria in the presence of this cichlid. In cultivated larvae, phytoplankton consumption comes second only to artificial food (RochA-LOURES 2001).

The size of the predator and the degree of development of its sensory structures (JHA et al. 2006), as well as the morphology of the gill rakers (HyatT 1979, WootTon 1992, Jobling

2015 | Sociedade Brasileira de Zoologia | www.sbzoologia.org.br | www.scielo.br/zool All content of the journal, except where identified, is licensed under a Creative Commons attribution-type BY. 
1996) influence the size of the prey and the way it is captured. In the initial stages of the development, some tilapia species prefer plankton (GROVER et al. 1989, UfoDiKE \& WADA 1991) and this item is present in significant concentrations in the stomach of O. niloticus fry and adults (Rocha Loures et al. 2001, BwaniKa et al. 2006). The gill rakers of the Nile tilapia may be long and numerous, a characteristic of plankton-feeding species, or few and short, which characterizes on omnivorous diet (CÂmara \& Chellappa 1996, Beyruth et al. 2004, Zayed \& Mohamed 2004).

The Nile Tilapia may cause different types of impact on the zooplankton community throughout its development, since this fish changes the way it captures and eats its prey. During the larval stages, when the tilapia's mouth cavity is small, most of the plankton is captured using visual predation (Yowell \& Vinyard 1993), but in older stages of development, filter-feeding becomes the tilapia's predominant means to trap zooplankton (Gophen et al. 1983, Lazzaro 1987, 1991). This is associated with loss of visual acuity in large fish, which causes them to interrupt their selective visual predation (НјеLм et al. 2000). This change in eating habits may occur abruptly (Moriarty et al. 1973, Beveridge \& Baird 2000), or more gradually (Whitfield \& BLADER 1978).

When tilapias become exclusively filter-feeders, they consume only small organisms (Beveridge \& BaIrd 2000). The least evasive organisms in the zooplankton community (Drenner et al. 1978, 1982a, b Drenner \& Mccomas 1980, Kohler \& Ney 1982, Bezerra-Neto \& Pinto-Coelho 2003), cladocerans and rotifers, are the most common prey of plankton-eating fish (Drenner et al. 1986, 1987, LazZaro 1987). In the study conducted by Menezes et al. (2010), the presence of fish at different stages of development seemed to affect the population density of cladocerans and rotifers differently. For example, in the presence of adult Nile tilapias, cladoceran populations increase, showing that adult tilapias do not favor this type of zooplankton. Conversely, when tilapia juveniles predominate, rotifer population density decreases (Menezes et al. 2010). On the other hand, due to their effective evasive behavior (STRICKLER 1977, Fields \& Yen 1996, Lenz \& Hartline 1999, Yen 2000), copepods are captured in low numbers when compared with similar-sized zooplanktonic organisms (Trager et al. 1994).

Even though they change how they capture prey during their ontogenetic development, Nile tilapias continue to eat organisms from the zooplankton community, even though the zooplankton groups ingested may vary. Since filter feeding affects organisms that get trapped in the gill rakers of fish, the space between these structures will determine the size of the prey ingested, determining that larger zooplanktonic organisms will be caught more often.

The objective of this study was to verify which zooplankton groups contribute the most to the diet of the omnivorous $O$. niloticus at the post-larval stage, in addition to determining if the way they prey selects their prey size. The hypothesis is that, as the gill rakers increase in size throughout this cichlid's ontogenetic development, predation exerts great pressure on larger zooplanktonic organisms.

\section{MATERIAL AND METHODS}

Juvenile Nile tilapia gift strain juvenile sex-reversed males average size $14 \mathrm{~cm}$ were stocked at density of $1.1 \mathrm{fish} / \mathrm{m}^{2}$ in 12 earthen ponds. These ponds were previously populated with natural plankton along with the Amazon river prawn, Macrobrachium amazonicum (Heller, 1862).

Stomach contents of fish were analyzed for four months, focusing on the zooplankton community. In addition, gill rakers of fish were measured to test for a correlation with the size of the ingested zooplankton. Fish were fed floating fish food twice a day. Primary environmental variables were regularly monitored and kept at culture standards. Once a month, one fish was randomly removed from each earthen pond with a fishing rod. Fish were fixed in formaldehyde (10\%) and then stored in alcohol (70\%). Stomachs and gills were extracted and fixed in formaldehyde (4\%). Stomach content analysis was carried out in three subsamples of one milliliter, obtained with Stempel pipette, placed on a Sedgewick-Rafter counting cell slide under an optical microscope equipped with a reticle in order to measure zooplankton. For the identification of zooplankton species, specific keys were used (Koste 1978a, b, Pontin 1978, Sendacz \& Kubo 1982, Reid 1985, Matsumura-Tundisi 1986, Segers 1995, El moorLoureiro 1997, Silva \& Matsumura-Tundisi 2005).Zooplankton species were measured depending on their percentage in the stomach contents of cichlid. For computing the monthly means of the size of ingested zooplankton, the number of measurements followed a scale of representativeness, that is, more individuals were measured from the species that were in a higher proportion. The size of the gill rakers was measured through a stereomicroscope equipped with a micrometric ocular. Ten measurements were obtained for each extracted gill, for a total of four gills per fish. Next, means of those measures were calculated, determining the mean gill raker length and the mean distance between gill rakers each month.

Data was subjected to Shapiro-Wilk test of normality, and according to the results the appropriate statistical analyses were applied. The results expressed in percentage were arcsine square root transformed before statistical analyses. In order to compare the mean percentage of zooplankton found in the stomach contents from $O$. niloticus, the Kruskal-Wallis nonparametric test was used, along with a multiple-comparison among means test, at 5\% significance. This test was also used to compare the mean percentage of each zooplanktonic group and the mean body size of the zooplankton ingested by the cichlid each month. In order to compare mean gill raker size, the parametric Anova with Tukey post hoc test (5\%) was used. Pearson's correlation (5\%) was employed to establish the correlation between size of ingested zooplankton and fish gill raker size. 


\section{RESULTS}

Approximately 15 zooplankton species were found in the diet of $O$. niloticus, distributed among copepods, cladocerans, and rotifers (Table 1). Among them, the most consumed were rotifers from the genera Brachionus Pallas, 1766 and Keratella Bory de St. Vincent, 1822 (Fig. 1). Among the microcrustaceans, the cladoceran Moina minuta Hansen, 1899 was the most abundant in fish stomach contents. The average percentage of zooplankton found in the stomach contents of O. niloticus was $3 \%$ and it did not differ throughout the study. Nevertheless, as fish grew, the contributions of each group of ingested zooplankton changed. Fish ingested more and more rotifers, and less and less microcrustaceans, and the decrease was particularly considerable in the third month and in the last stomach analysis, which verified that no microcrustacean was consumed (Fig. 1). The consumption of rotifers increased with age, whereas the size of ingested prey decreased. In addition, gill raker length and the space between gill rakers increased as fish grew (Table 2). A significant negative correlation between zooplankton body width and the space between gill rakers was observed (Fig. 2). Other negative correlations were observed, though marginally significant (Figs. 2 and 3).

\section{DISCUSSION}

During their development from post-larval to adult stages, Nile tilapia ingested the same percentage of zooplankton with respect to the rest of their diet, but they consumed different zooplankton groups. Such changes may be related to the way $O$. niloticus preys. This study confirmed that juvenile Nile tilapia ingest cladocerans, as well as copepods and rotifers, through both visual predation and filter-feeding. Since rotifers are less likely to escape tilapia predation, they are the main zooplankton in the diet of this fish. Adults stop consuming microcrustaceans through visual predation and begin to eat only rotifers, which they catch through filter feeding.

According to several studies (Grover et al. 1989, UfODIKE \& WADA 1991, Rocha Loures et al. 2001, BwANiKa et al. 2006), the percentage of zooplankton ingested decreases in the diet of species of Oreochromis, as fry develop into adults; it becomes constant, which was also observed in this study. A preference for zooplankton and diatoms to artificial food was observed during the first stages of Nile tilapia larvae (Ufodike \& WADA 1991). Nevertheless, this preference changed as larvae grew, as observed by Grover et al. (1989) when studying fry of red hybrid tilapia: they increase their consumption of artificial food as they develop. Even so, the consumption of zooplankton by tilapia may be significant, as observed by BWANIKA et al. (2006) in African ponds, where the percentage of zooplankton in the stomach contents of $O$. niloticus varied from 8 to 13\%. Even Nile tilapia fry, which were fed artificial food, phytoplankton and zooplankton, had a stomach content of approximately 13\% zooplankton (Rocha Loures et al. 2001).

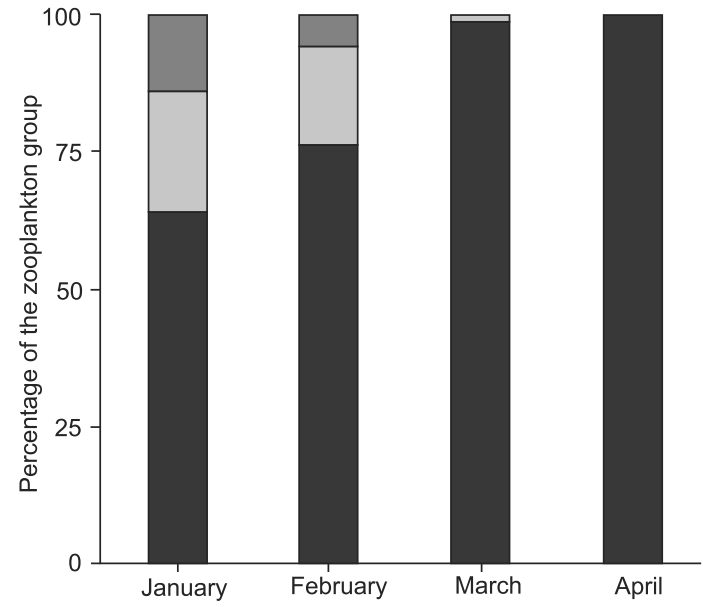

Figure 1. Zooplankton composition in the stomach contents from Oreochromis niloticus each month. ( $\square)$ Copepoda, ( $\square$ ) Cladocera, (घ) Rotifera.
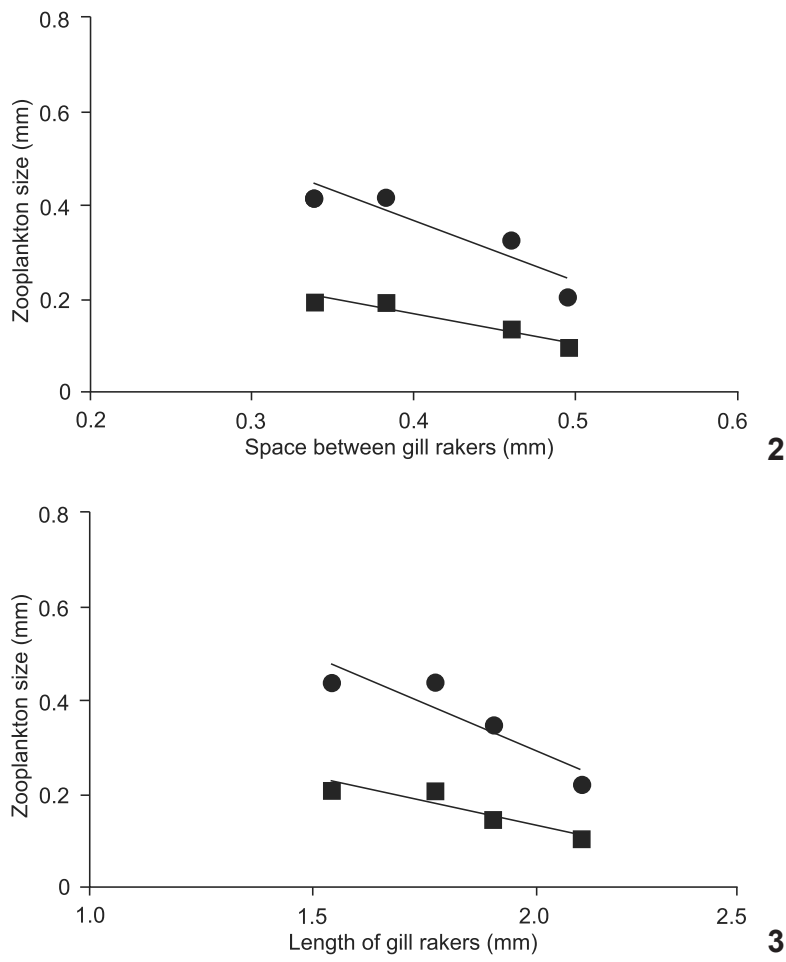

Figures 2-3. (2) Negative correlation between zooplankton's body size found in stomach contents and space between Nile tilapia's gill rakers. Significant Pearson's correlation (Length $r=-0.92$ and $p=0.07$; Width $r=-0.96$ and $p=0.04$ ). (3) Negative correlation between zooplankton's body size found in stomach contents and length of Nile tilapia's gill rakers. Significant Pearson's correlation (Length $r=-0.91$ and $p=0.09$; Width $r=-0.92$ and $p=0.08$ ). (๑) Length, (ם) width. 
Table 1. Zooplankton community and respective size variations found in the diet of post-larval stages (juvenile to adult) of Oreochromis niloticus throughout four months.

\begin{tabular}{|c|c|}
\hline Taxon/month & Length $(\mathrm{mm})$ \\
\hline \multicolumn{2}{|l|}{ January } \\
\hline \multicolumn{2}{|l|}{ Cladocera } \\
\hline Diaphanosoma spinulosum & $0.33-0.88$ \\
\hline Moina minuta & $0.37-0.83$ \\
\hline \multicolumn{2}{|l|}{ Copepoda } \\
\hline Copepodid & $0.33-0.83$ \\
\hline Nauplius & $0.11-0.33$ \\
\hline Notodiaptomus iheringi & $0.77-1.65$ \\
\hline Thermocyclops decipiens & $0.50-1.00$ \\
\hline \multicolumn{2}{|l|}{ Rotifera } \\
\hline Brachionus calyciflorus & $0.22-0.44$ \\
\hline Brachionus havanaensis & $0.28-0.33$ \\
\hline Filinia spp. & $0.11-0.17$ \\
\hline Keratella spp. & $0.11-0.17$ \\
\hline Lecane spp. & $0.11-0.17$ \\
\hline Trichocerca sp. & $0.22-0.33$ \\
\hline \multicolumn{2}{|l|}{ February } \\
\hline \multicolumn{2}{|l|}{ Cladocera } \\
\hline Diaphanosoma spinulosum & $0.33-0.99$ \\
\hline Moina minuta & $0.33-0.77$ \\
\hline \multicolumn{2}{|l|}{ Copepoda } \\
\hline Argyrodiaptomus furcatus & $1.16-1.49$ \\
\hline Copepodid & $0.33-0.99$ \\
\hline Nauplius & $0.20-0.55$ \\
\hline Notodiaptomus iheringi & $0.94-1.54$ \\
\hline \multicolumn{2}{|l|}{ Rotifera } \\
\hline Brachionus calyciflorus & $0.22-0.39$ \\
\hline Brachionus falcatus & $0.28-0.36$ \\
\hline Brachionus havanaensis & $0.22-0.39$ \\
\hline Filinia spp. & $0.11-0.22$ \\
\hline Lecane spp. & $0.12-0.17$ \\
\hline Trichocerca sp. & $0.18-0.33$ \\
\hline \multicolumn{2}{|l|}{ March } \\
\hline \multicolumn{2}{|l|}{ Cladocera } \\
\hline Moina minuta & $0.33-0.77$ \\
\hline \multicolumn{2}{|l|}{ Rotifera } \\
\hline Brachionus calyciflorus & $0.28-0.44$ \\
\hline Brachionus havanaensis & $0.25-0.39$ \\
\hline Filinia spp. & $0.08-0.33$ \\
\hline Keratella spp. & $0.11-0.22$ \\
\hline Lecane spp. & $0.12-0.19$ \\
\hline Trichocerca sp. & $0.18-0.33$ \\
\hline \multicolumn{2}{|l|}{ April } \\
\hline \multicolumn{2}{|l|}{ Rotifera } \\
\hline Brachionus havanaensis & $0.22-0.39$ \\
\hline Filinia spp. & $0.20-0.22$ \\
\hline Keratella spp. & $0.11-0.22$ \\
\hline Lecane spp. & $0.14-0.17$ \\
\hline Trichocerca sp. & $0.20-0.22$ \\
\hline
\end{tabular}

Table 2. Size variation from Oreochromis niloticus and their structures responsible for filtering zooplankton community throughout the study. Values are means ( \pm standard deviation).

\begin{tabular}{lccc}
\hline Month & $\begin{array}{c}\text { O. niloticus }(\mathrm{cm}) \\
( \pm \mathrm{SD})\end{array}$ & $\begin{array}{c}\text { Length of the gill } \\
\text { rakers }(\mathrm{mm})( \pm \mathrm{SD})\end{array}$ & $\begin{array}{c}\text { Space between the gill } \\
\text { rakers }(\mathrm{mm})( \pm \mathrm{SD})\end{array}$ \\
\hline January & $14( \pm 0.69)^{\mathrm{c}}$ & $1.54( \pm 0.12)^{\mathrm{c}}$ & $0.34( \pm 0.05)^{\mathrm{b}}$ \\
February & $18( \pm 1.29)^{\mathrm{bc}}$ & $1.77( \pm 0.13)^{\mathrm{b}}$ & $0.38( \pm 0.04)^{\mathrm{b}}$ \\
March & $21( \pm 2.08)^{\mathrm{ab}}$ & $1.90( \pm 0.14)^{\mathrm{b}}$ & $0.46( \pm 0.04)^{\mathrm{a}}$ \\
April & $23( \pm 1.16)^{\mathrm{a}}$ & $2.10( \pm 0.15)^{\mathrm{a}}$ & $0.50( \pm 0.05)^{\mathrm{a}}$ \\
\hline
\end{tabular}

Means with different letters in each column differ statistically. Kruskal-Wallis $(5 \%)$ and ANOVA Tukey (5\%), $\mathrm{p}<0.05$.

The size of the prey and how they are captured may differ, depending on the size of the predator and the development of their sensory structures (JнA et al. 2006). During an experiment with Nile tilapia larvae, Ufodike \& WADA (1991) demonstrated that the first stages of larvae (5 to $14 \mathrm{~mm}$ ) predate rotifers, cladocerans, and copepods. BEYRuTH et al. (2004) also observed the great proportion of rotifera and cladocera in the digestive system of $O$. niloticus fry. According to their data, during the first post-larval stages, Nile tilapia may still prey on zooplankton. Our data showed that O. niloticus adults stopped ingesting microcrustaceans and began to prey only on rotifers. During its adult stage the percentage of zooplankton in their diet remained constant. Tilapia predation on the rotifer population may have significant impact, as observed by Menezes et al. (2010), through population data analysis.

Studies carried out with filter feeding fish have demonstrated that species that have low escapement capacity are predated in greater numbers (Drenner et al. 1986, 1987, LazZAro 1987). Among the zooplankton, rotifers and cladocerans have the least mobility and escapement capacity (DrEnNER et al. 1978, 1982a, b, Drenner \& Mccomas 1980, Kohler \& Ney 1982, BezerraNeto \& Pinto-Coelho 2003). Copepods, on the other hand, are the most evasive (Drenner et al. 1978, Lazzaro 1987, 1991). The total absence of copepoda in the diet of O. niloticus adults confirms that they escape from the flow pumped by the fish during the filtering process (DrenNER et al. 1978, LAZZARo 1987, 1991). Rotifers, which have lower escapement efficiency than microcrustaceans, constituted $100 \%$ of the adult tilapia's zooplankton diet. In a study on the effects of predation on plankton populations, AtTAYde \& Menezes (2008) concluded that rotifer populations grow in the presence of juvenile Nile tilapias, whereas cladoceran populations increase in the presence of adults, suggesting that during the juvenile stage, these fish feed more on microcrustaceans than on rotifers, and during adulthood, the opposite happens. Menezes et al. (2010) also noted an increase in rotifera biomass in the absence of tilapia in the environment, showing that rotifers may be one of the most consumed groups by this fish.

During filtering, the gill rakers of the Nile tilapia secrete mucus, trapping food items (LAZZARO 1987, SANDERSON et al. 1996, ZaVALA-CAMIN 1996). The morphology of the gill rakers is di- 
rectly related to the size of the ingested prey (НуAтT 1979, Wootton 1992, Jobling 1996). In several studies on the diet of O. niloticus, it was observed that this cichlid may have different types of gill rakers. The high trophic plasticity of the Nile tilapia indicates that it may have long and numerous gill rakers (plankton-feeding species), or few and short ones (omnivorous species) (CÂmara \& Chellappa 1996, Beyruth et al. 2004, ZaYed \& Mohamed 2004). Fish gill rakers in this study showed characteristics of omnivorous species, with the space between them being wider than the dimensions of most zooplankton prey. Around $85 \%$ of the zooplankton found in the stomach contents was smaller than the space between the gill rakers, which means that they would go through the filter if there was no mucus. Among the zooplankton organisms identified, rotifers were the smallest ones. The remaining ingested prey (15\%) were larger than the space between the gill rakers. However, the ingestion of large microcrustaceans happened only during the first months of culture, during the initial post-larval stage. In adults, the space between the gill rakers is larger, which results in a lower contribution from larger-sized zooplankton and a higher contribution from minute zooplankton organisms. This may indicate that the presence of mucus in adult $O$. niloticus is one of the main factors in prey capture, not the space between the gill rakers. In addition, the mucus secreted in the gill rakers does not trap large zooplankton. Even though the gill rakers increase in length, and the amount of secreted mucus increases with age, these potential prey individuals have not been ingested by adults, despite the elevated population density of cladocerans and copepods.

The highest contribution of microcrustaceans such as copepods during the first life stages of fish is related to visual active capture, during which the predator spots and ingests the prey intentionally (LAzZARo 1987). Studies have shown that $O$. niloticus fry prey only visually, ingesting rotifers, cladocerans and copepods (Ufodike \& WADA 1991, Beyruth et al. 2004), a common characteristic of several groups of fish (GopHen et al. 1983, Lazzaro 1987, 1991). According to Yowell \& VinYard (1993), the reduced volume of the mouth cavity of the tilapia during the larval stages results in a strictly visual predation. For Yowell \& Vinyard (1993), the change in how prey is ingested (from visual predation to filter feeding) occurs when the tilapia's body reaches six centimeters in length. Although our study was carried out with juvenile $O$. niloticus measuring, on average, 14 centimeters, it was concluded that copepods and cladocerans microcrustaceans were actively ingested during this post-larval stage. In the stomach of adults, only small zooplankton was found, such as rotifers, confirming data from study by BEVERIDGe \& BAIRD (2000), which suggests that filtering has an impact on minute zooplankton.

In conclusion, during the development of O. niloticus, the way fish ingest zooplankton and the groups of zooplankton they ingest change. Juvenile fish prey on microcrustaceans visually and filter feed rotifers, whereas adult individuals filter feed zooplankton, which consist of smaller-sized organisms that are trapped in the mucus secreted by their gill rakers.

There are changes in the contribution from zooplankton species to the diet of $O$. niloticus throughout the ontogenetic development of the fish. The consumption of microcrustaceans verified in the post-larval stage is replaced by the total contribution of rotifers during the adult stage.

The increase in the size of the gill raker of $O$. niloticus does not determine the consumption of larger zooplankton prey. Despite their abundance in the environment, this group of zooplankton, mainly represented by copepods, is not ingested at the same rate as rotifers, because they are efficient in escaping from predation. We also conclude that, when capturing prey through filter feeding, the presence of mucus produced by the fish in the gills plays a more effective role than the space between the gill rakers. Also, the greater representation of microcrustaceans during the Nile tilapia's first post-larval stages (when they are already filter feeding), allows us to deduce that, at this stage, there is still visual predation, which is more efficient for capturing larger zooplankton prey, such as microcrustaceans.

\section{ACKNOWLEDGMENTS}

The authors thank Centro de Aquicultura da Unesp (Caunesp) from Jaboticabal-SP and their entire working group. This study was sponsored by Coordenação de Aperfeiçoamento de Pessoal de Nível Superior and Conselho Nacional de Pesquisa (Proc. 473199/2011-4).

\section{LITERATURE CITED}

Attayde JL, Menezes RF (2008). Effects of fish biomass and planktivore type on plankton dynamics. Journal of Plankton Research 30(8): 885-892. doi: 10.1093/plankt/fbn051

Attayde JL, Iskin M, Carneiro L (2006) O papel da Onivoria na Dinâmica de Cadeias Alimentares. Oecologia brasiliensis 10(1): 69-77.

Attayde JL, Okun N, Brasil J, Menezes RF, Mesquita P (2007) Impactos da introdução da tilápia do Nilo, Oreochromis niloticus, sobre a estrutura trófica dos ecossistemas aquáticos do Bioma Caatinga. Oecologia Brasiliensis 11(3): 450-461. doi: 10.4257/oeco.2007.1103.13

Beveridge MCM, Baird DJ (2000) Diet, feeding and digestive physiology, p. 59-87. In: Beveridge MCM, McANdrew BJ (Eds.) Tilapias: Biology and Exploitation. Stirling, University of Stirling. doi: 10.1007/978-94-011-4008-9_3

Beyruth Z, Mainardes-Pinto CSR, Fusco SM, Faria FC, Silva AL (2004) Utilização de alimentos naturais por Oreochromis niloticus em tanques de terra com arraçoamento. Boletim do Instituto de Pesca 30(1): 9-24.

Bezerra-Neto JF, Pinto-Coelho RM (2003) Avaliação da eficiência de dois amostradores na estimativa da abundância e biomassa de organismos planctônicos. Bios 11(11): 19-27. 
Bwanika GN, Chapman LJ, Kizito Y, Balirwa J (2006) Cascading effects of introduced Nile Perch (Lates niloticus) on the foraging ecology of Nile tilapia (Oreochromis niloticus). Ecology of Freshwater Fish 15: 470-481. doi: 10.1111/ j.1600-0633.2006.00185.x

CÂMARA MR, Chellappa S (1996) Regime alimentar e adaptações morfo-anatômicas do trato digestivo dos Ciclídeos (Pisces: Cichlidae). Boletim do DOL/CB/UFRN 9: 59-66.

Diana JS, Lin CK, Bhukaswan T, Sirsumanatach V, Buurma BJ (1991) Data Report, Volume Two, Number three. Thailand: Cycle III of the Global Experiment. PD/A CRSP, Oregon State University, Corvallis, Oregon, 86p.

Drenner RW, McComas SR (1980) The role of zooplankton escape ability and fish size selectivity in the selective feeding and impact of planktivorous fish, p. 587-593. In: КеRFOOT WC (Ed.) Evolution and Ecology of Zooplankton Communities. Hanover, University Press of New England, XXIII+793p.

Drenner RW, Strickler JR, O'Brien WJ (1978) Capture probability. The role of zooplankter escape in the selective feeding of planktivorous fish. Journal of Fisheries Research Board of Canada 35(10): 370-1373. doi: 10.1139/f78-215

Drenner RW, De Noyelles-Jr F, Kettle D (1982a) Selective impact of filter-feeding gizzard shad on zooplankton community structure. Limnology and Oceanography 27(5): 965-968. doi: 10.4319/lo.1982.27.5.0965

Drenner RW, Vinyard GL, Gophen M, McComas SR (1982b) Feeding behavior of the cichlid, Sarotherodon galilaeum: selective predation on Lake Kinneret zooplankton. Hydrobiologia 87: 17-20. doi: 10.1007/BF00016658

Drenner RW, Threlkeld ST, MCcracken MD (1986) Experimental analysis of the direct and indirect effects of an omnivorous filter feeding clupeid on plankton community structure. Canadian Journal of Fisheries and Aquatic Sciences 43: 1935-1945. doi: 10.1139/f86-239

Drenner RW, Hambright HD, Vinyard GL, Gophen M, Pollingher U (1987) Experimental study of size-selective phytoplankton grazing by a filter-feeding cichlid and the cichlid's effects on plankton community structure. Limnology and Oceanography 32(5): 1138-1144.

Elhigzi FAR, Haider SA, Larsson P (1995) Interaction between Nile tilapia (Oreochromis niloticus) and cladocerans in ponds (Khartoum, Sudam). Hydrobiologia 307: 263-272. doi: $10.1007 /$ BF00032020

El Moor-Loureiro LMA (1997) Manual de Identificação de Cladóceros Límnicos do Brasil. Brasília, Universa, 156p.

Fields DM, Yen J (1996) The escape behavior of Pleuromamma xiphias from a quantifiable fluid mechanical disturbance, p. 323-340. In: Lenz PH, Hartline DK, Purcell JE, Macmillan DL (Eds.) Zooplankton: Sensory Ecology and Physiology. Amsterdam, Gordon \& Breach Science Publishers.

Figueredo CC, Giani A (2005) Ecological interactions between Nile tilapia (Oreochromis niloticus, L.) and the phytoplanktonic community of the Furnas Reservoir (Brazil). Freshwater
Biology 50: 1391-1403. doi: 10.1111/j.1365-2427.2005.01407.x Gophen M, Drenner RW, Vinyard GG (1983) Fish introductions into Lake Kinneret - Call for Concern. Aquaculture Research 14(1): 43-45. doi: 10.1111/j.1365-2109.1983.tb00053.x

Grover JJ, Olla BL, O’Brien M, Wicklund RI (1989) Food habits of Florida Red Tilapia fry in natured seawater pools in the Bahamas. The Progressive Fish-Culturist 51(3): 152-156. doi: 10.1577/1548-8640(1989)051<0152:FHOFRT>2.3.CO;2

Hjelm J, Persson L, Christensen B (2000) Growth, morphological variation and ontogenetic niche shifts in perch (Perca fluviatilis) in relation to resource availability. Oecologia 122: 190-199. doi: 10.1007/PL00008846

HyatT KD (1979) Feeding Strategy, p. 71-119. In: Hoar WS, Randall DJ, Brett JR (Eds.) Fish Physiology. Bioenergetics and Growth. New York, Academic Press, vol. 7, XVII+786p.

Jha BR, Waidbacher H, Sharma S, Straif M (2006) Fish species composition, number and abundance in different rivers and seasons in Nepal and the reevaluation of their threat category for effective conservation and management. Ecology, Environment \& Conservation 12 (1): 25-36.

JoвLING M (1996) Environmental Biology of Fishes. London, Chapman \& Hall, 455p.

Kohler CC, Ney JJ (1982) A comparison of methods for quantitative analysis of feeding selection of fishes. Environmental Biology of Fishes 7(4): 363-368.

Koste W (1978a) Rotatoria. Die Rodertiere Mitteleuropas begründet von Max Voigt - Monogononta. 2. Auflage neubearbeitet von Walter Koste. (I - Textband). Berlin, Gebrüder Borntraeger, 673p.

Koste W (1978b) Rotatoria. Die Rodertiere Mitteleuropas begründet von Max Voigt -

Monogononta. 2. Auflage neubearbeitet von Walter Koste. (II - Tafelband). Berlin, Gebrüder Borntraeger, 238p.

Lazzaro X (1987) A review of planktivorous fishes: their evolution, feeding, behaviours, selectivities and impacts. Hydrobiologia 146: 97-167. doi: 10.1007/BF00008764

Lazzaro X (1991) Feeding convergence in South American and African zooplanktivorous cichlids Geophagus brasiliensis and Tilupiu rendalli. Environmental Biology of Fishes 31: 283-293.

Lenz PH, Hartline DK (1999) Reaction times and force production during escape behavior of a calanoid copepod, Undinula vulgaris. Marine Biology 133(2): 249-258. doi: 10.1007/ s002270050464

Matsumura-Tundisi T (1986) Latitudinal distribution of Calanoida copepods in freshwater aquatic systems of Brazil. Revista Brasileira de Biologia 46(3): 527-553.

Menezes RF, Attayde JL, Vasconcelos FR (2010) Effects of omnivorous filter-feeding fish and nutrient enrichment on the plankton community and water transparency of a tropical reservoir. Freshwater Biology 55: 767-779. doi: 10.1111/j.1365-2427.2009.02319.x

Moriarty JW, Darlington JPEC, Dunn IG, Moriarty CM, Tevlin MP (1973) Feeding and Grazing in Lake George, Uganda. Proceedings 
of the Royal Society of London. Series B, Biological Sciences 183(1076): 299-319. doi: 10.1098/rspb.1973.0050

Pontin RM (1978) Freshwater planktonic and semi-planktonic Rotifera of the British Isles. Ambleside, Freshwater Biological Association Scientific Publication, 178p.

REID JW (1985) Chave de identificação e lista de referências bibliográficas para as espécies continentais sul-americanas de vida livre da Ordem Cyclopoida (Crustacea, Copepoda). Boletim de Zoologia da Universidade de São Paulo 9: 17-143.

Rocha Loures BTR, Ribeiro RP, Vargas L, Moreira HLM, Sussel FR, Povh JA, Cavichiolo F (2001) Manejo alimentar de alevinos de tilápia do Nilo, Oreochromis niloticus (L.), associado às variáveis físicas, químicas e biológicas do ambiente. Acta Scientiarum Animal Sciences 23(4) 877-883.

Sanderson SL, Stebar MC, Ackermann KL, Jones SH, Batjakas IE, Kaufman L (1996) Mucus entrapment of particles by a suspension-feeding tilapia (Pisces: Cichlidae). Journal of Experimental Biology 199: 1743-1756.

Segers H (1995) Rotifera 2: The Lecanidae (Monogononta), p. 1-226. In: Dumont HJF (Ed.) Guides to the identification of the microinvertebrates of the continental waters of the world. Amsterdam, SPB Academic Publishing.

Sendacz S, Kubo E (1982) Copepoda (Calanoida e Cyclopoida) de reservatórios do Estado de São Paulo. Boletim do Instituto de Pesca 9: 51-89.

Silva WM, Matsumura-Tundisi T (2005) Taxonomy, ecology, and geographical distribution of the species of the genus Thermocyclops Kiefer, 1927 (Copepoda, Cyclopoida) in São Paulo State, Brazil, with description of a new species. Brazilian Journal Biology 65(3): 521-531. doi: 10.1590/S1519-69842005000300018

STRICKLER JR (1977) Observation of swimming performances of planktonic copepods. Limnology and Oceanography 22(1): 165-170. doi: 10.4319/lo.1977.22.1.0165
Trager G, Achituv Y, Genin A (1994) Effects of prey escape ability, flow speed and predator feeding mode on zooplankton capture by barnacles. Marine Biology 120(2): 251-259. doi: 10.1007/BF00349685

Turker H, Eversole AG, Brune DE (2003a) Filtration of green algae and cyanobacteria by Nile tilapia, Oreochromis niloticus, in the Partitioned Aquaculture System. Aquaculture 215: 93-101. doi: 10.1016/S0044-8486(02)00133-3

Turker H, Eversole AG, Brune DE (2003b) Comparative Nile tilapia and silver carp filtration rates of Partitioned Aquaculture System phytoplankton. Aquaculture 220: 449457. doi: 10.1016/S0044-8486(02)00614-2

Ufodike EBC, WAda RK (1991) Feeding habits of tilapia, Sarotherodon nilotica (Perciformis: Cichlidae) fry in Jos, Nigeria. Revista de Biología Tropical 39(2): 189-192.

Whitfield AK, BLADER SJM (1978) Food and feeding ecology of piscivorous fishes at Lake St. Lucia, Zululand. Journal of Fish Biology 13: 675-691. doi: 10.1111/j.1095-8649.1978.tb03481.x

Wootton RJ (1992) Fish Ecology. New York, Chapman and Hall, 212p.

YEN J (2000) Life in transition: balancing inertial and viscous forces by planktonic copepods. Biological Bulletin 198: 213-224. doi: $10.2307 / 1542525$

Yowell DW, VINYARD GL (1993) An energy-based analysis of particulate-feeding and filter-feeding by blue tilapia, Tilapia aurea. Environmental Biology of Fishes 36(1): 65-72. doi: 10.1007/BF00005980

ZAVALA-CAMIN LA (1996) Introdução aos estudos sobre alimentação natural em peixes. Maringá, EDUEM, 129p.

ZAYEd AE, Mohamed SA (2004) Morphological study on the gills of two species of fresh water fishes: Oreochromis niloticus and Clarias gariepinus. Annals of Anatomy 186(4): 295-304. doi: 10.1016/S0940-9602(04)80044-X
Submitted: 4 May 2015

Received in revised form: 17 July 2015

Accepted: 23 September 2015

Editorial responsibility: Vinicius Abilhoa 